\title{
Micropropagation of pokeweed (Phytolacca americana L.) and comparison of phenolic, flavonoid content, and antioxidant activity between pokeweed callus and other parts
}

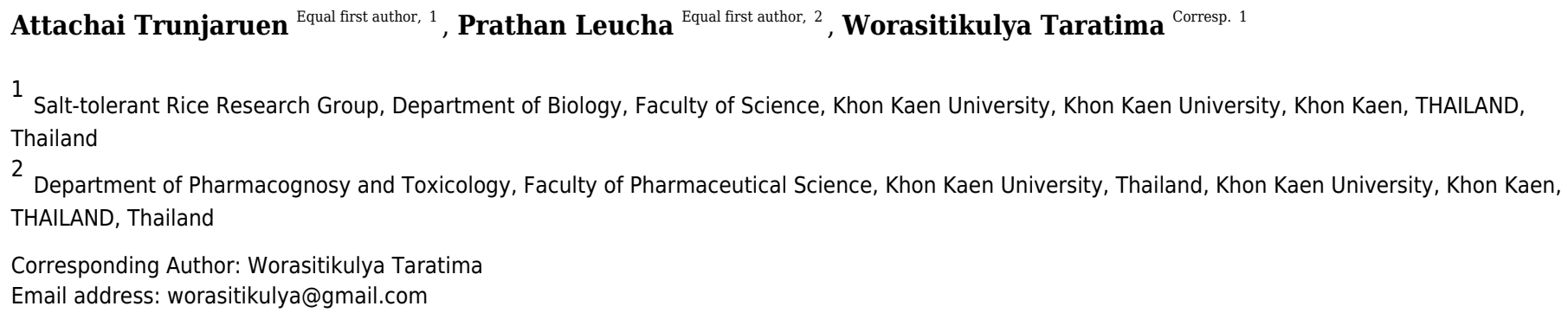

Background. Pokeweed (Phytolacca americana L.) is regarded as an invasive plant in many parts of the world but possesses therapeutic characteristics used for antitumor and rheumatism treatment. This study investigated the effects of auxins and four explants on pokeweed callus induction. The effects of cytokinins and combinations between cytokinins and NAA on shoot and root induction were also studied. TPC, TFC and antioxidant activity of calli were screened and compared with other pokeweed plant parts. Methods. Four explants were used to induce callus using 2,4-D and IBA at 1, 2, 3 and $4 \mathrm{mg} / \mathrm{l}$ for each auxin. Direct shoot organogenesis from nodal explants was investigated using BAP, kinetin and TDZ (1, 2 and $4 \mathrm{mg} / \mathrm{l}$ for each cytokinin). Combined effects between cytokinins and NAA at $0.1,0.2$ and $0.3 \mathrm{mg} / \mathrm{l}$ were further simultaneously estimated with root induction. Calli derived from the leaves were compared with other plant parts for TPC, TFC and antioxidant activity using the Folin-Ciocalteu, $\mathrm{AlCl}_{3}$ colorimetric assay and DPPH assays, respectively. Results. Results showed that MS medium containing $2 \mathrm{mg} / \mathrm{l}$ 2,4-D induced callus formation on leaf explants that provided highest fresh and dry weights. Three types of synthetic cytokinins as kinetin, TDZ and BAP were used for direct shoot organogenesis from pokeweed nodes. MS medium containing $2 \mathrm{mg} / \mathrm{l}$ kinetin was effective in stimulating normal shoots, with the largest number of shoots and leaves and the longest shoots. The combination between cytokinins and NAA showed no positive effect on shoot and root induction from pokeweed nodal explants. For TPC and TFC determination, pokeweed seeds and leaves possessed the highest phenolic and flavonoid contents, respectively. Highest phenolic content of pokeweed seeds led to lowest $\mathrm{IC}_{50}$ by DPPH assay. Phenolic content was higher than flavonoid content. Conclusion. Results suggested promising conditions for callus induction. Leaf explants cultured on MS medium with $2 \mathrm{mg} / \mathrm{l}$ 2,4-D and nodal explants cultured on MS medium with $2 \mathrm{mg} / \mathrm{l}$ kinetin provided the largest number of 
normal shoots and leaves. NAA did not show positive effects on shoot and root induction when combined with cytokinins. Chemical constituent screening indicated that seeds and leaves provided highest TPC and TFC, respectively while pokeweed calli contained higher phenolic than flavonoid content. This is the first report describing chemical constituent screening and antioxidant activity of calli and other parts of the pokeweed plant. Results provided significant information to further enhance bioactive compound contents of pokeweed calli using elicitation methods. 
1 Micropropagation of pokeweed (Phytolacca americana

2 L.) and comparison of phenolic, flavonoid content,

3 and antioxidant activity between pokeweed callus and

4 other parts

${ }^{1}$ Salt-tolerant Rice Research Group, Department of Biology, Faculty of Science, Khon Kaen University, Khon Kaen, Thailand

2 Department of Pharmacognosy and Toxicology, Faculty of Pharmaceutical Science,

Corresponding Author:

Department of Biology, Faculty of Science, Khon Kaen University, Khon Kaen 40002, Thailand

Email address: worasitikulya@gmail.com

\section{Abstract}

Background. Pokeweed (Phytolacca americana L.) is regarded as an invasive plant in many parts of the world but possesses therapeutic characteristics used for antitumor and rheumatism treatment. This study investigated the effects of auxins and four explants on pokeweed callus induction. The effects of cytokinins and combinations between cytokinins and NAA on shoot and root induction were also studied. TPC, TFC and antioxidant activity of calli were screened and compared with other pokeweed plant parts.

Methods. Four explants were used to induce callus using 2,4-D and IBA at 1, 2, 3 and $4 \mathrm{mg} / \mathrm{l}$ for each auxin. Direct shoot organogenesis from nodal explants was investigated using BAP, kinetin and TDZ (1, 2 and $4 \mathrm{mg} / \mathrm{l}$ for each cytokinin). Combined effects between cytokinins and NAA at $0.1,0.2$ and $0.3 \mathrm{mg} / \mathrm{l}$ were further simultaneously estimated with root induction. Calli derived from the leaves were compared with other plant parts for TPC, TFC and antioxidant activity using the Folin-Ciocalteu, $\mathrm{AlCl}_{3}$ colorimetric assay and DPPH assays, respectively.

Results. Results showed that MS medium containing $2 \mathrm{mg} / \mathrm{l}$ 2,4-D induced callus formation on leaf explants that provided highest fresh and dry weights. Three types of synthetic cytokinins as kinetin, TDZ and BAP were used for direct shoot organogenesis from pokeweed nodes. MS medium containing $2 \mathrm{mg} / \mathrm{l}$ kinetin was effective in stimulating normal shoots, with the largest number of shoots and leaves and the longest shoots. The combination between cytokinins and NAA showed no positive effect on shoot and root induction from pokeweed nodal explants. For 
flavonoid contents, respectively. Highest phenolic content of pokeweed seeds led to lowest $\mathrm{IC}_{50}$ by DPPH assay. Phenolic content was higher than flavonoid content.

Conclusion. Results suggested promising conditions for callus induction. Leaf explants cultured on MS medium with $2 \mathrm{mg} / \mathrm{l}$ 2,4-D and nodal explants cultured on MS medium with $2 \mathrm{mg} / \mathrm{l} \mathrm{kinetin}$ provided the largest number of normal shoots and leaves. NAA did not show positive effects on shoot and root induction when combined with cytokinins. Chemical constituent screening indicated that seeds and leaves provided highest TPC and TFC, respectively while pokeweed calli contained higher phenolic than flavonoid content. This is the first report describing chemical constituent screening and antioxidant activity of calli and other parts of the pokeweed plant. Results provided significant information to further enhance bioactive compound contents of pokeweed calli using elicitation methods.

Keywords: antioxidant, callus, chemical constituents, micropropagation, pokeweed

\section{Introduction}

Phytolacca americana L. or pokeweed (family Phytolaccaceae), is widely distributed as a native weed in North America and regarded as an invasive plant in many parts of the world (Balogh \& Juhasz, 2008). Pokeweed seeds are phenolic-rich and possess interesting biological properties. Seed derivative americanin A shows antitumor activity for human colon cancer, while isoamericanin B and C inhibit tyrosinase activity (Jung et al., 2015; Petrillo et al., 2019). However, copious quantities of roots and seeds would be required for commercial purposes and plant tissue culture is now an effective technique to produce large numbers of plants and also metabolites that can be used for medicinal purposes.

Mass plant production within a limited time is the major advantage of the plant tissue culture technique (Bhoite \& Palshikar, 2014). Callus can be induced from all parts of plants and used as materials for plant regeneration to stimulate production of bioactive compounds. Direct shoot organogenesis is a process whereby new shoots are directly produced from other vegetative parts (Bhatia \& Bera, 2015). Callus induction and direct shoot organogenesis are different manipulation methods, and factors influencing both processes represent the balance between auxins and cytokinins. High ratios of auxins and cytokinins induce roots, while low ratios induce shoots from explants and equal ratios promote callus induction (Ikeuchi et al., 2013). However, optimal concentrations of auxins and cytokinins need to be estimated for plant species and specific types of explants. Therefore, it is necessary to select types of explants that are appropriate for micropropagation.

Most previous research about pokeweed micropropagation focused on direct shoot organogenesis Zou et al. (2008) and El-Minisy et al. (2017) but research concerning callus induction of pokeweed is limited. Pokeweed callus induction was first established for cell suspension production. Sakuta et al. (1991) induced calli from pokeweed stems and cultured and produced pokeweed cell suspension from the calli. Some phytochemicals, like betalains, can be produced from calli and cell suspension. Consequently, this study determined the effects of auxins 
and explant types on pokeweed callus induction to obtain calli that could be used for chemical constituents and antioxidant activity determination. The effects of PGRs and explants on direct shoot organogenesis were also evaluated for more efficient pokeweed micropropagation. Total phenolic and flavonoid contents and total antioxidant activity by DPPH assay were also evaluated to compare phytochemical content between the callus and other parts of wild plants.

\section{Materials \& Methods}

\section{Plant materials}

Pokeweed plants were cultivated, and seeds were obtained from ripened pokeweed fruits grown in

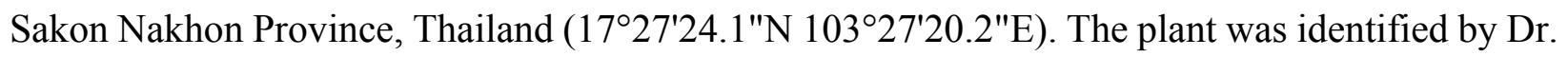
Sakuntala Ninkaew, and the specimens were deposited at KKU herbarium (KKU No. 26576). For in vitro germination, pokeweed seeds were soaked in concentrated sulfuric acid for $10 \mathrm{~min}$ and then rinsed with running tap water. Seeds were then sterilized by agitation with $2 \%(\mathrm{v} / \mathrm{v})$ sodium hypochlorite for $30 \mathrm{~min}$ and rinsed with sterilized distilled water for $5 \mathrm{~min}$ three times. The sterilized seeds were cultured on solid Murashige and Skoog (MS; 1962) medium supplemented with $30 \mathrm{~g} / 1$ sucrose (pH 5.8). Cultures were incubated at $25 \pm 2{ }^{\circ} \mathrm{C}$ with a $16 / 8 \mathrm{~h}$ (light/dark) cycle at $40 \mu \mathrm{mol} \cdot \mathrm{m}^{-2} \cdot \mathrm{s}^{-1}$ light intensity. Media and equipment were sterilized by autoclaving at $121^{\circ} \mathrm{C}$ for 20 min. Cotyledons, leaves, nodes and internodes were obtained from in vitro grown plants aged 2 months after germination. Cotyledons and leaf explants were cut into $1 \times 1 \mathrm{~cm}$ squares, and $1 \mathrm{~cm}$ long nodal and internodal explants were used for callus induction and direct shoot organogenesis.

\section{Callus induction}

Cotyledons, leaves, nodes and internodes from in vitro grown pokeweed were used as initial explants. Solid MS medium fortified with $30 \mathrm{mg} / \mathrm{l}$ of sucrose (pH 5.8) was used as basal medium and supplemented with 2,4-D and IBA at 1, 2, 3 and $4 \mathrm{mg} / \mathrm{l}$ for both PGRs. MS medium without PGRs was considered as the control. Callus induction cultures were maintained under aseptic conditions at $25 \pm 2{ }^{\circ} \mathrm{C}$ with a $16 / 8 \mathrm{~h}$ (light/dark) cycle at $40 \mu \mathrm{mol} \cdot \mathrm{m}^{-2} \cdot \mathrm{s}^{-1}$ light intensity for four weeks before data collection.

Survival, response and callus formation percentages were calculated at week four after callus induction. Explants showing viable characteristics were considered as surviving. Response percentages were estimated from the surviving explants as changes in growth. Explants with callus formation were used to calculate callus induction percentage, fresh weight and dry weight. For dry weight, the calli were dried at $45^{\circ} \mathrm{C}$ for 3 days.

\section{Direct shoot organogenesis}

Explants of cotyledons, leaves, nodes and internodes were used as plant materials. Solid MS medium with $30 \mathrm{~g} / 1$ sucrose (pH 5.8) was supplemented respectively with three types of synthetic cytokinins as BAP, kinetin and TDZ applied for each cytokinin at 1, 2 and $4 \mathrm{mg} / \mathrm{l}$. MS medium without PGRs was considered as the control. The cultures were maintained under aseptic 
118 conditions at $25 \pm 2{ }^{\circ} \mathrm{C}$ with a $16 / 8 \mathrm{~h}$ (light/dark) cycle at $40 \mu \mathrm{mol} \cdot \mathrm{m}^{-2} \cdot \mathrm{s}^{-1}$ light intensity for six 119 weeks before data collection.

120

121

122

123

124

125

126

127

128

129

130

131

132

133

134

135

136

137

138

139

140

141

142

143

144

145

146

147

148

149

150

151

152

153

154

155

156

157

Survival percentages, response, callus formation, and root and shoot formation percentages were collected six weeks after culture for direct shoot organogenesis. Explants with shoots and roots were used to calculate shoot and root formation percentage. Number of shoots per explant, shoot length and number of leaves per shoot were evaluated simultaneously.

\section{Combined effects of cytokinins and auxins}

From four explant types, only nodal explants showed potential for shoot organogenesis. Therefore, nodes from in vitro grown pokeweeds were used as plant materials in this experiment. Solid MS media ( $\mathrm{pH} 5.8$ ) with three cytokinin conditions as $1 \mathrm{mg} / \mathrm{l} \mathrm{BAP,} 2 \mathrm{mg} / \mathrm{l}$ kinetin and $1 \mathrm{mg} / \mathrm{l} \mathrm{TDZ}$ were combined with four concentrations of NAA (0, 1, 2 and $3 \mathrm{mg} / \mathrm{l})$. MS medium without PGRs was considered as the control. The cultures were maintained under aseptic conditions at $25 \pm 2{ }^{\circ} \mathrm{C}$ with a $16 / 8 \mathrm{~h}$ (light/dark) cycle at $40 \mu \mathrm{mol} \cdot \mathrm{m}^{-2} \cdot \mathrm{s}^{-1}$ light intensity for six weeks before data collection.

Percentages of survival, response, callus formation and root and shoot formation were collected at six weeks after culture for direct shoot organogenesis. Explants with shoots and roots were used to calculate shoot and root formation percentages. Number of shoots per explant, shoot length and number of leaves per shoot were evaluated simultaneously.

\section{Chemical constituents and antioxidant activity}

Calli induced from leaf explants cultured on MS medium added with $2 \mathrm{mg} / 1$ 2,4-D, leaves, roots and seeds were dried at $45{ }^{\circ} \mathrm{C}$ for 3 days. All samples were ground and then extracted with methanol. Briefly, $100 \mathrm{mg}$ of powdered sample were extracted with $1 \mathrm{ml}$ of methanol and sonicated for $30 \mathrm{~min}$ at $30{ }^{\circ} \mathrm{C}$. The extraction was repeated three times and the extract solutions were assembled. Methanol was evaporated using a vacuum oven at $45{ }^{\circ} \mathrm{C}$ for $48 \mathrm{~h}$. The extracts were used to determine chemical constituents and antioxidant activities.

Total phenolic content of the pokeweed callus extract was determined and compared with TPC of other plant parts using the Folin-Ciocalteu assay with some modifications following Mwamatope et al. (2020). Extracts at $20 \mu \mathrm{l}$ were mixed with $100 \mu \mathrm{l}$ of 10-fold diluted FolinCiocalteu solution and then added with $80 \mu \mathrm{l}$ sodium carbonate $\left(\mathrm{Na}_{2} \mathrm{CO}_{3}\right)$ in microplates. The microplates were incubated in darkness for $30 \mathrm{~min}$. TPC was determined at $760 \mathrm{~nm}$ and calculated as mg gallic acid equivalent (GAE)/g dry weight extract.

Total flavonoid content of pokeweed callus extract was determined and compared with TFC of other plant parts based on the complex between flavonoid compounds and aluminum chloride $\left(\mathrm{AlCl}_{3}\right)\left(\right.$ Pekal \& Pyrzynska 2014). Extracts at $100 \mu \mathrm{l}$ were mixed with $50 \mu 1$ of $2 \% \mathrm{AlCl}_{3}$ and 50 $\mu 1$ of water in microplates. The reaction was carried out in the dark for $30 \mathrm{~min}$, determined at 425 $\mathrm{nm}$ and calculated as mg quercetin equivalent $(\mathrm{QE}) / \mathrm{g}$ dry weight extract.

DPPH assay was carried out following the method of Mwamatope et al. (2020). The solution was incubated with DPPH reagent for $30 \mathrm{~min}$ at room temperature under dark condition. After 
158

159

160

161

162

163

164

165

166

167

168

169

170

171

172

173

174

175

176

177

178

179

180

181

182

183

184

185

186

187

188

189

190

191

192

193

194

195

196

197

incubation, absorbance was measured at $517 \mathrm{~nm}$ using a spectrophotometer. Methanol and ascorbic acid were used as negative and positive controls, respectively. Free radical scavenging activity was calculated by the following equation.

$\%$ free radical scavenging activity by DPPH $=[1-($ A sample $/$ A control $)] \times 100$

A sample means the absorbance of sample solution, while A control denotes the absorbance of negative control, with both measured at $517 \mathrm{~nm}$.

\section{Statistical analysis}

All experiments were carried out with ten replications per treatment. Data were analyzed by oneway Analysis of Variance (ANOVA) and means were separated using Least Significant Difference (LSD; $p<0.05$ ). Data were expressed as mean \pm standard error of mean (SE). Statistical analysis was performed with Statistix 10 software.

\section{Results}

\section{Effects of explant types and auxins on callus induction}

Results showed that all types of explants survived and responded in all treatments without significant difference. Cotyledons and leaves only generated calli in media with 2,4-D, while roots were induced from explants by media supplemented respectively with IBA and NAA (Fig. 1A). Similar responses were also found in treatments of nodal and internodal explants cultured in the media with IBA (Fig. 1B). Interestingly, shoot formation was observed only in the treatments of nodal explants cultured on MS medium without PGRs and media with IBA, singly (Fig. 1C). This phenomenon showed the shoot organogenesis potential of pokeweed nodal explants.

This experiment identified conditions that were suitable for callus induction of pokeweed. Calli from all treatments showed similar morphology as friable with pink to purple color. Observation under a stereomicroscope revealed elongated parenchymal cells, mostly with accumulated green or purple pigment and some elongated and clear without pigment (Fig. 1D). Considering callus induction percentage, all explant types cultured on media containing 2,4-D produced calli leading to $100 \%$ callus induction percentage in those treatments $(\mathrm{P}$-value $=0.00$; Table 1$)$. Callus production was also observed in treatments of internodes and nodes cultured on media with IBA, ranging $37.50-62.50 \%$ and $56.25-81.25 \%$, respectively. However, callus percentages from IBA treatments were significantly lower than those from 2,4-D treatments (P-value $=0.00$; Table 1). Significantly highest callus fresh weight was obtained from nodes cultured on medium containing $3 \mathrm{mg} / \mathrm{l} \mathrm{IBA}$ (Fig. 1B) and leaves cultured on medium containing 2 $\mathrm{mg} / 1$ 2,4-D (Fig. 1E) at $0.81 \mathrm{~g}$ and $0.80 \mathrm{~g}$, respectively while these two treatments also provided the highest dry weights of calli at $0.05 \mathrm{~g}(\mathrm{P}-\mathrm{value}=0.00$; Table 1). Callus induction percentage of leaf explants cultured on $2 \mathrm{mg} / 1$ 2,4-D reached $100 \%$, while nodes cultured on $3 \mathrm{mg} / 1 \mathrm{IBA}$ provided only $62.50 \%$ (Table 1$)$. Fresh and dry weights of calli generated from leaf explants (0.69-0.80 g and 0.04-0.05 g, respectively) were higher than calli from other explants (Table 1). Therefore, 
198

199

200

201

202

203

204

205

206

207

208

209

210

211

212

213

214

215

216

217

218

219

220

221

222

223

224

225

226

227

228

229

230

231

232

233

234

235

236

culture of leaf explants on MS medium supplemented with $2 \mathrm{mg} / 1$ 2,4-D was the most appropriate for callus induction from pokeweed.

\section{Effects of explant types and cytokinins on direct shoot organogenesis}

Different types and concentrations of cytokinins were tested with cotyledon, leaf, internodal and nodal explants of pokeweed to induce direct shoot organogenesis. Six weeks after culture, percentages of root formation, shoot formation, number of shoots per explant, shoot length and number of leaves per shoot were recorded. Most treatments produced callus, while only nodal explants produced roots in the control treatment (Fig. 1F). Cotyledon explants turned from green to purple in treatments of control and kinetin without any other changes, while color change was also found when leaf explants were cultured on the control medium.

Shoot formation percentages were calculated to identify suitable conditions for direct shoot organogenesis. Results showed that only nodal explants produced novel shoots that emerged directly from the leaf axillary. All treatments provided 100\% shoot formation percentage, except for the control that gave $37.50 \%$ and significantly lower than the others (P-value $=0.00$; Table 2 ). All treatments provided new shoots from the explants, but some abnormalities were observed from these shoots and leaves. In the control treatment, generated shoots gave expanding leaves with slender stems, which were considered normal characteristics (Fig. 1F). Shoots from BAP and TDZ treatments showed aberrations such as curling at the leaf margin and fleshy thick stems (Fig. 1G and $1 \mathrm{H}$ ), whereas more slender and less fleshy stems with normal leaves were observed in treatments of kinetin (Fig. 1I). The number of shoots per explant, shoot length and number of leaves per shoot were also recorded. Treatment of $1 \mathrm{mg} / \mathrm{l} \mathrm{TDZ}$ provided significantly largest number of shoots per explant (2.43 shoots), while nodal explants cultured on medium with $2 \mathrm{mg} / \mathrm{l}$ kinetin gave significantly longest shoots and largest number of leaves per shoot as $5.04 \mathrm{~cm}$ and 10.93 leaves, respectively (P-value $=0.00$; Table 2 ). Interestingly, all treatments except for the control generated callus at the basal part of nodal explants. In each type of explant, cytokinin concentrations at 1,2 and $1 \mathrm{mg} / 1$ gave significantly highest number of shoots, shoot length and number of leaves for BAP, kinetin and TDZ, respectively. Therefore, these concentrations were used in the basal medium to investigate the combined effects of cytokinins and auxins on direct shoot organogenesis.

\section{Combined effects of cytokinins and auxins on direct shoot organogenesis}

According to the previous study, $1 \mathrm{mg} / \mathrm{l} \mathrm{BAP}, 2 \mathrm{mg} / \mathrm{l} \mathrm{kinetin}$ and $1 \mathrm{mg} / 1 \mathrm{TDZ}$ as suitable conditions for direct shoot organogenesis were combined with $0.1,0.2$ and $0.3 \mathrm{mg} / 1 \mathrm{NAA}$ to optimize conditions for direct shoot organogenesis and root induction simultaneously. The same parameters with the previous experiments were collected after culture for six weeks. Results showed that survival and response percentages were not affected by these combinations, leading to $100 \%$ in all treatments. However, shoots from control that could have roots emerged from the base, while the media containing both cytokinin and NAA could not produce root from the explants (Table 3). 
237

238

239

240

241

242

243

244

245

246

247

248

249

250

251

252

253

254

255

256

257

258

259

260

261

262

263

264

265

266

267

268

269

270

271

272

273

274

275

276

The control treatment gave $37.50 \%$ shoot formation, significantly lower than percentages from other treatments that all recorded $100 \%(\mathrm{P}$-value $=0.00$; Table 3). Abnormal morphology increased when NAA concentration increased, for example curling at the leaf margin, nonexpanding leaves and fleshy stems. Media supplemented with $2 \mathrm{mg} / \mathrm{l}$ kinetin combined with 0.1 and $0.2 \mathrm{mg} / \mathrm{l} \mathrm{NAA}$ showed significantly largest number of shoots per explant ( 2.5 shoots; P-value $=0.00$ ). For shoot length and number of leaves per shoot, the highest parameters were obtained from single treatment of $2 \mathrm{mg} / 1$ kinetin as $5.04 \mathrm{~cm}$ and 10.93 leaves, respectively (P-value $=0.00$; Table 3). Interestingly, these parameters tended to decrease when concentration of NAA combined with each type of cytokinin increased (Table 3). Therefore, parameters from media supplemented with only each cytokinin were higher than those from treatments of cytokinin-auxin combination.

\section{Chemical constituents and antioxidant activity}

Phenolic and flavonoid contents and $\mathrm{IC}_{50}$ values for DPPH assay of the four explants were determined as preliminary screening of some bioactive pokeweed compounds. Parameters of calli, leaves, roots and seeds of pokeweed were compared (Table 4). Results demonstrated that pokeweed seeds provided the highest phenolic content as $155.83 \mathrm{mg} \mathrm{GAE} / \mathrm{g}$ dry weight extract, while calli, leaves and roots had significantly lower phenolic content than seeds ranging from 14.03 to 26.03 (P-value $=0.00$ ). The flavonoid content of pokeweed leaves was significantly higher than other explants $(57.31 \mathrm{mg}$ QE/g dry weight extract). Pokeweed seeds and roots contained lower flavonoid content than leaves as 49.81 and $33.46 \mathrm{mg} \mathrm{QE} / \mathrm{g}$ dry weight extract, respectively while pokeweed calli had the lowest flavonoid content $(11.73 \mathrm{mg}$ QE/g dry weight extract; P-value $=0.00$ ).

Antioxidant activities of the four pokeweed explants were determined and compared with ascorbic acid as control using DPPH assay and expressed inhibitory concentration at 50\% $\left(\mathrm{IC}_{50}\right)$. Pokeweed seeds and ascorbic acid had significantly lowest $\mathrm{IC}_{50}$ at 12.66 and $3.91 \mu \mathrm{g} / \mathrm{ml}$, respectively. Higher $\mathrm{IC}_{50}$ values were obtained from leaves and calli at 228.70 and $341.99 \mu \mathrm{g} / \mathrm{ml}$, respectively, while roots showed the highest $\mathrm{IC}_{50}$ at $11256.51 \mu \mathrm{g} / \mathrm{ml}$. These results demonstrated that pokeweed calli from in vitro culture generated phenolic and flavonoid compounds that were responsible for antioxidant activity determined by DPPH assay.

\section{Discussion}

\section{Different responses of explants to auxins in pokeweed callus induction}

Different types of pokeweed explants from aseptic plants were cultured on MS medium with 2,4-D and IBA at various concentrations to investigate the effects of explant types and auxins on callus induction efficiency. Survival and response percentage from all treatments were not affected but fresh and dry weight of calli were strongly influenced. Remarkably, callus from any part of pokeweed showed green to purple, resulting from the betacyanin pigments accumulated in callus cells (Sakuta et al., 1991).

Our results found that calli derived from leaf explants had larger fresh and dry weights than calli derived from other explants. The success of callus induction from leaf explants was also 
277 reported in Vanda sp. as callus induction from leaf segments (Budisantoso et al., 2017). Possible 278 reasons for the success were high stomatal density and spongy mesophyll that facilitated nutrients 279 and PGR uptake, therefore, leaf explants provided high callus efficiency (Zhang et al., 2020). 280 These reasons were also valid for callus induction from cotyledons that have stomata and spongy 281 mesophyll. Recent results showed that fresh and dry weight of cotyledon-derived calli were similar 282 to calli from leaf explants. In lotus (Nelumbo nucifera), four explant types were tested for callus 283 induction. Results showed that immature cotyledons were suitable for callus induction of lotus, 284 with $20 \%$ callus formation after three weeks of culture (Deng et al., 2020). However, our results 285 showed adverse results of nodal and internodal explants, while some previous studies 286 demonstrated the positive effects of those explants. Kumlay \& Ercisli (2015) recorded high 287 performance for callus induction from nodal explants of potato (Solanum tuberosum). They 288 explained that potato leaves have a large surface area with high rate of water loss, while lower 289 290

291

292

293

294

295

296

297

298

299

300

301

302

303

304

305

306

307

308

309

310

311

312

313

314

315

316

surface area and stomata of nodal explants led to better efficiency of callus induction. Our results confirmed that differences in explant histology affected callus induction efficiency and response of explants to PGRs.

The balance of PGRs in growth media is a vital factor that affects plant callus induction. Equal ratios of auxins and cytokinins promoted callus induction (Ikeuchi et al., 2013) but appropriate types and concentrations of auxins and cytokinins must first be considered as PGRs for specific plant species. Most studies reported that exogenous auxins were necessary for callus induction. Therefore, here, we focused on the effects of auxin types and concentrations on callus induction of pokeweed. In this study, 2,4-D and IBA were applied with different pokeweed explants. Results showed that callus induction media containing 2,4-D induced calli from all types of explants, consistent with previous studies. Callus induction from bamboo (Dendrocalamus hamiltonii) was carried out by shoot tip culture on medium with $3 \mathrm{mg} / 1$ 2,4-D and $1 \mathrm{mg} / 1$ benzyladenine (Zang et al., 2016). Callus induction medium with $2 \mathrm{mg} / 1$ 2,4-D was identified as the optimal condition for landrace rice (Oryza sativa) from Thailand (Trunjaruen et al., 2020). Auxins, e.g., 2,4-D and NAA in callus induction medium were reported to promote expression of important genes like $L B D$ family and ARF19 (Ikeuchi et al., 2013), resulting in callus formation. Supplementation of 2,4-D also induced several genes involving signal transmission and overexpression of transcription factors ZmBBM in maize (Zea mays) that induced callus formation from their scutella (Du et al., 2019). All these genes have been proved for involvement of auxins with callus formation under in vitro conditions.

Some studies have investigated pokeweed cell suspensions. Medium supplemented with $1 \mathrm{mg} / \mathrm{l}$ 2,4-D was used for callus induction from stem explants and cell suspension establishment from those calli (Sakuta et al., 1986; Sakuta et al., 1991). However, reports about the effects of explant types and other auxins on callus induction are limited. Therefore, this study determined improved and reliable conditions for pokeweed callus induction. The calli obtained from this study could be also extracted and determined phenolic, flavonoid content, and antioxidant activity.

Peer) reviewing PDF | (2021:09:65649:1:0:NEW 5 Dec 2021) 


\section{Direct shoot organogenesis influenced by explant and cytokinin types}

318 Callus induction is a vital step for plant micropropagation because callus can be applied as the

319

320

321

322

323

324

325

326

327

328

329

330

331

332

333

334

335

336

337

338

339

340

341

342

343

344

345

346

347

348

349

350

351

352

353

354

355

356 initial materials for indirect organogenesis. However, our preliminary experiments demonstrated that indirect shoot organogenesis could not be induced from calli, therefore, direct shoot organogenesis was an alternative method to produce in vitro pokeweed plantlets. The plantlets can be used for pokeweed propagation, while leaves from the plantlets can also be used as explants for callus induction.

In a recent study, we investigated the effects of cytokinins on direct shoot organogenesis of pokeweed from different types of explants. Our results showed that new shoots were only generated from nodal explants and were induced in all treatments. Several studies reported the success of direct shoot organogenesis from nodal explants. Direct shoot organogenesis of maize was carried out with nodal explants cultured on medium supplemented with $1.8 \mathrm{mg} / \mathrm{l}$ benzyladenine (Mushke et al., 2016), while compared with three different nodal explants, Tylophora indica showed the highest efficiency of direct shoot organogenesis (Najar et al., 2018). New shoots emerged from the leaf axils of nodal explants, possibly influenced by apical dominance that promoted multiple shoots (Oliveira et al., 2013).

Our findings revealed that nodal explants from all treatments provided new shoots. The control treatment gave lowest shoot formation percentage, while other treatments reached $100 \%$ (Table 2 ). These results proved that applications of exogeneous cytokinins had positive effects on direct shoot organogenesis, consistent with many previous studies. A concentration of $3 \mathrm{mg} / \mathrm{l} \mathrm{BAP}$ was reported as the optimal condition over other cytokinins for direct shoot regeneration of potato tree (Solanum erianthum; Sarkar \& Banerjee, 2020). In direct shoot organogenesis of Cryptocoryne wendtii, shoot tips in the control treatment gave lower shooting percentage than treatments of BAP and kinetin, while the appropriate cytokinin conditions for direct shoot organogenesis was $3 \mathrm{mg} / \mathrm{l}$ kinetin (Klaocheed et al., 2020). For direct shoot organogenesis of apple, appropriate types and concentrations of cytokinins mainly depended on genotypes and initial explants (Magyar-Tabori et al., 2010). The AHK4/WOL cytokinin receptor is the major component in shoot regeneration and induces many downstream genes. Overexpression of $A R R 1$ and WUS, which are normally upregulated by AHK4/WOL, promoted shoot regeneration in a cytokinin-free medium (Ikeuchi et al., 2019). This information proved that cytokinins promote shoot regeneration through the regulation of gene expression.

Results showed that $1 \mathrm{mg} / 1 \mathrm{TDZ}$ provided the largest number of shoots per explant, while shoots from treatments of TDZ showed abnormalities like thick and succulent stems and curling leaves. These characteristics were considered as hyperhydricity or vitrification, as phenomena that always occur in plants grown under in vitro conditions (Kevers et al., 2004). Micropropagated pear showed higher hyperhydricity in the shoots from TDZ treatments than benzyladenine and kinetin (Kadota \& Niimi, 2003). Therefore, treatment of $2 \mathrm{mg} / \mathrm{l}$ kinetin was considered to be the most suitable conditions for pokeweed direct shoot organogenesis because novel shoots were not abnormal, with longest short length and highest number of leaves as 1.81 shoots per explant, 5.04 cm length and 10.94 leaves per shoot (Table 2). 
357

358

359

360

361

362

363

364

365

366

367

368

369

370

371

372

373

374

375

376

377

378

379

380

381

382

383

384

385

386

387

388

389

390

391

392

393

394

395

396

Previous studies reported protocols for direct shoot organogenesis of pokeweed. MS medium with $2.0 \mathrm{mg} / 1$ benzyladenine and $0.2 \mathrm{NAA} \mathrm{mg} / \mathrm{l}$ was appropriate for direct shoot induction from stem segments of pokeweed (Zou et al., 2008). MS medium supplemented with $2 \mathrm{mg} / \mathrm{l}$ BAP and $0.2 \mathrm{mg} / \mathrm{l}$ NAA provided 2.6 shoots generated from stem segments, higher than our results (El-Minisy et al., 2017). However, micropropagated shoots reported by El-Minisy et al. (2017) were longer with greater numbers of leaves than previous studies. As well as direct shoot organogenesis, callus generation was induced from the base of micropropagated shoots in all treatments except for the control. This proved that the application of cytokinins stimulated callus formation through the cytokinin-mediated callus formation pathway (Ikeuchi et al., 2013).

Our results provided promising conditions for direct shoot organogenesis, which gave abundant pokeweed shoots that could be further propagated. The leaves from in vitro plantlets could also be used as explants for callus induction.

\section{Combined effects between cytokinins and auxin}

Three cytokinins as BAP, TDZ and kinetin at 1,2 and $1 \mathrm{mg} / 1$, respectively were selected from the highest efficiency of shoot organogenesis from the previous experiment. These treatments were combined with $0.1,0.2$ and $0.3 \mathrm{mg} / 1 \mathrm{NAA}$. Results showed that kinetin treatments tended to increase the number of shoots, while other parameters decreased (Table 3). Application of NAA with cytokinins produced vitrified shoots with thick and fleshy stems and abnormal leaves.

Most previous studies reported positive effects of cytokinin-auxin combination on shoot organogenesis. Multiple shoots of Ruta graveolens were induced from shoot tip meristems by MS medium supplemented $2.25 \mathrm{mg} / \mathrm{l}$ benzyladenine and $0.47 \mathrm{mg} / 1 \mathrm{NAA}$ (Faisal et al., 2018). Positive effects of the combination were also reported in pokeweed shoot induction. Zou et al. (2008) induced new pokeweed shoots from stem segments using $2 \mathrm{mg} / 1 \mathrm{BA}$ and $0.2 \mathrm{mg} / 1 \mathrm{NAA}$, while 1 $\mathrm{mg} / \mathrm{l} \mathrm{BAP}$ combined with $0.2 \mathrm{mg} / \mathrm{l} \mathrm{NAA}$ was found to be suitable for shoot regeneration from stem cuttings (El-Minisy et al., 2017). However, our results showed that single cytokinins gave better results than cytokinin-auxin combination treatments. Similar results were also found in shoot multiplication of Amygdalus communis apical shoot tips. Shoot formation was not observed in treatments containing benzyladenine and kinetin combined with NAA (Akbas et al., 2009). In this study, we hypothesized that the addition of NAA with cytokinins may induce shoots and roots, simultaneously. However, the results indicated that media fortified with cytokinins and NAA did not affect pokeweed root induction. A high ratio between cytokinins and auxins was suitable for shoot induction (Ikeuchi et al., 2013). We also found that micropropagated shoots showed some vitrified characters when NAA concentration increased. Hyperhydricity may result from excessive concentrations of PGRs (Karimpour et al., 2013). Therefore, we suggested that $2 \mathrm{mg} / \mathrm{l}$ kinetin without supplementation with NAA could induce multiple shoots of pokeweed from nodal explants. 
397

398

399

400

401

402

403

404

405

406

407

408

409

410

411

412

413

414

415

416

417

418

419

420

421

422

423

424

425

426

427

428

429

430

431

432

433

434

435

436

\section{Chemical constituents and antioxidant activity}

Among all callus induction treatments, leaf explants cultured on MS medium added with $2 \mathrm{mg} / \mathrm{l}$ 2,4-D gave calli with the highest dry weight. Nazir et al. (2020) found that the highest biomass purple basil (Ocimum basilicum L. var purpurascens) calli provided the highest phenolic and flavonoid contents. Therefore, calli possessing the highest dry weight were used to determine phenolic and flavonoid contents and antioxidant activity and compared with other pokeweed plant parts.

Different parts of pokeweed possess diverse major secondary metabolites. Here, phenolic and flavonoid contents of various pokeweed explants were determined to preliminarily screen the chemical constituents, and the results showed that pokeweed seeds provided the highest phenolic content. Neo-lignans and phenolic compounds accumulated mainly in pokeweed seeds (Bailly, 2021). These phenolic compounds have many medicinal properties and may be responsible for high antioxidant activity, as shown by the lowest $\mathrm{IC}_{50}$ value in DPPH assay. Other explants showed lower phenolic content, especially in roots. Results proved that phenolic compounds were not the major accumulated compounds in leaves and roots. Leaves accumulated the highest flavonoid content compared with other explants. Flavonoid content was also higher than phenolic content in leaves and roots. The major secondary metabolites stored in leaves and roots were not phenolics and flavonoids. Research on chemical constituents of pokeweed leaves is limited but it has been reported that the leaves are green and their veins are always purple due to the accumulation of betacyanins (Jerz et al., 2008), while there was strong evidence that triterpenes and phytosterols accumulated in pokeweed roots (Choe et al., 2020; Jeong et al., 2004).

Previous studies of pokeweed callus chemical constituents focused on betacyanin extraction. Callus induced from leaf explants also showed purple pigments of betacyanins (Kobayashi et al., 1995; Fig. 1D), while betacyanins were also extracted from cell suspension maintained under aseptic conditions (Sakuta et al., 1991). Recent studies reported that low levels of phenolic and flavonoid contents accumulated in pokeweed calli resulted in low antioxidative potential. Similar results were found in most research. Calli of Helicteres angustifolia produced lower phenolic, flavonoid and saponin contents than the wild roots (Yang et al., 2019). Phenolic and flavonoid contents of blueberry (Vaccinium corymbosum) calli were lower than field-grown and in vitro leaves (Kolarevic et al., 2021). The phenomenon could be explained by the dedifferentiated property of the callus that resulted in lesser production and accumulation of complicated metabolites (Kolarevic et al., 2021; Yang et al., 2019). Lower metabolite contents in callus may result from limited metabolite production by in vitro explants but could be enhanced by callus elicitation to reduce cost and time to obtain pokeweed seeds and roots possessing major compounds of pokeweeds.

\section{Conclusions}

Pokeweed plants possess medicinal properties and may be applied in agricultural and medicinal fields. This study investigated the effects of explant types and auxins on pokeweed callus induction. Results showed that all types of explants generated callus by the application of 
437

438

439

440

441

442

443

444

445

446

447

448

449

450

451

452

453

454

455

456

457

458

459

460

461

462

463

464

465

466

467

468

469

470

471

472

473

474

475

exogenous 2,4-D. Suitable conditions for callus induction were culture of leaf explants on MS medium supplemented with $2 \mathrm{mg} / 1$ 2,4-D. This study proposed an improved and reliable system for pokeweed callus induction. In direct shoot organogenesis, pokeweed nodes were the only explant type for multiple shoot induction by cytokinins. Shoots with normal characteristics and largest number of shoots and leaves with the longest shoots were induced from MS medium fortified with $2 \mathrm{mg} / 1$ kinetin. We also found that inhibitory effects of combination with vitrified shoots increased when NAA concentration was increased. This study proposed an effective method for fast multiplication of pokeweed to utilize the plant in several fields. Pokeweed seeds showed the highest phenolic contents and lowest $\mathrm{IC}_{50}$ by DPPH assay, while leaves contained the highest flavonoid contents. Pokeweed calli showed higher phenolic than flavonoid content. This is the first report describing chemical constituent screening and antioxidant activity of calli and other parts of the pokeweed plant.

\section{References}

Bailly C. 2021. Medicinal properties and anti-inflammatory components of Phytolacca (Shanglu). Digital Chinese Medicine 4: 159-169.

Balogh L, Juhasz M. 2008. American and Chinese pokeweed (Phytolacca americana L., Ph. Esculenta van Houtte). In: Botta-Dukat Z, Balogh L., eds. The most important invasive plants in Hungary. HAS Institute of Ecology and Botany, 35-46.

Bhatia S, Bera T. 2015. Somatic embryogenesis and Organogenesis. In: Bhatia S., ed. Modern Applications of Plant Biotechnology in Pharmaceutical Science. Elsevier Inc., 209-230.

Bhoite HA, Palshikar GS. 2014. Plant Tissue Culture: A Review. World Journal of Pharmaceutical Science 2:565-572.

Budisantoso I, Amalia N, Kamsinah. 2017. In Vitro Callus Induction from Leaf Explants of Vanda sp Stimulated by 2,4-D. Biosaintifika 9(3): 492-497.

Choe S, Jeong S, Jang M, Yeom H, Moon S, Kang M, Yang W, Kim S. 2020. Identification of phytolaccosides in biological samples from pokeweed intoxication patients using liquid chromatography-tandem mass spectrometry. Journal of Chromatography B 1149. Article 122123.

Deng X, Xiong Y, Li J, Liu J, Sun H, Song H, Wang Y, Ma J, Liu Y, Yang M. 2020. The Establishment of an Efficient Callus Induction System for Lotus (Nelumbo nucifera). Plants 9: Article 1436 DOI 10.3390/plants9111436.

Du X, Fang T, Liu Y, Huang L, Zang M, Wang G, Liu Y, Fu J. 2019. Transcriptome Profiling Predicts New Genes to Promote Maize Callus Formation and Transformation. Frontiers in Plant Science 10: Article 1633 DOI 10.3389/fpls.2019.01633.

El-Minisy AM, El-Sawy A, El-Shabrawi HM, Soliman MH, El-Assal S, Mahfouze HA. 2017. In vitro Propagation and Molecular Analysis of Pokeweeds (Phytolacca americana) Plant. Middle East Journal of Agriculture 6: 424-432.

Peer] reviewing PDF | (2021:09:65649:1:0:NEW 5 Dec 2021) 
476

477

478

479

480

481

482

483

484

485

486

487

488

489

490

491

492

493

494

495

496

497

498

499

500

501

502

503

504

505

506

507

508

509

510

511

512

513

514

515

Ikeuchi M, Sugimoto K, Iwase A. 2013. Plant callus: Mechanisms of Induction and Regression. The Plant Cell 25: 3159-3173.

Ikeuchi M, Favero DS, Sakamoto Y, Iwase A, Coleman D, Rymen B, Sugimoto K. 2019. Molecular Mechanisms of Plant Regeneration. Annual Reviews of Plant Biology 70: 377-406.

Jerz G, Skotzki T, Fiege K, Winterhalter P, Wybraniec S. 2008. Separation of betalains from berries of Phytolacca americana by ion-pair high-speed counter-current chromatography. Journal of Chromatography A 1190: 63-73.

Jeong SI, Kim KJ, Choi MK, Keum KS, Lee S, Ahn SH, Back SH, Song JH, Ju YS, Choi BK, Jung KY. 2004. $\alpha$-Spinosterol Isolated from the Root of Phytolacca americana and its Pharmacological Property on Diabetic Nephropathy. Plant Medica 70: 736-739.

Jung C, Homg J, Bae SY, Kang SS, Park HJ, Lee SK. 2015. Antitumor Activity of Americanin A Isolated from the Seeds of Phytolacca americana by Regulating the ATM/ATR Signaling Pathway and the Skp2-p27 Axis in Human Colon Cancer Cells. Journal of Natural Products 78: 2983-2993.

Kadota M, Niimi Y. 2003. Effects of cytokinin types and their concentrations on shoot proliferation and hyperhydricity in in vitro pear cultivar shoots. Plant Cell, Tissue and Organ Culture 72: 261-265.

Kevers C, Franck T, Strasser RJ, Dommes J, Gasper T. 2004. Hyperhydricity of micropropagated shoots: a typically stress-induced change of physiological state. Plant Cell, Tissue and Organ Culture 77: 181-191.

Klaocheed S, Jehsu W, Choojun W, Thammasiri K, Prasertsongskun S, Rittirat S. 2020. Induction of Direct Shoot Organogenesis from Shoot Tip Explants of an Ornamental Aquatic Plant, Cryptocoryne wendtii. Walailak Journal of Science and Technology 17: 293-302.

Kobayashi A, Hagihara K, Kajiyama S, Kanzaki H, Kawazu K. 1995. Antifungal compounds induced in the dual culture with Phytolacca americana callus and Botryis fabae. Zeitschrift fur Naturforschung C. Journal of Biosciences 50: 398-402.

Kolarevic T, Milincic DD, Vujovic T, Gasic UM, Prokic L, Kostic AZ, Cerovic R, Stanojevic SP, Tesic ZL, Pesic MB. 2021. Phenolic Compounds and Antioxidant Properties of Field-Grown and In Vitro Leaves, and Calluses in Blackberry and Blueberry. Horticulturae 7: Article 420.

Magyar-Tabori K, Dobranszki J, Silva JAT, Bulley SM, Hudak I. 2010. The role of cytokinins in shoot organogenesis in apple. Plant Cell, Tissue and Organ Culture 101: 251-267.

Mushke R, Yarra R, Bulle M. 2016. Efficient in vitro direct shoot organogenesis from seedling derived split node explants of maize (Zea mays L.). Journal of Genetic Engineering and Biotechnology 14: 49-53.

Mwamatope B, Tembo D, Chikowe I, Kampira E, Nyirenda C. 2020. Total phenolic contents and antioxidant activity of Senna singueana, Melia azedarach, Moringa 
516

517

518

519

520

521

522

523

524

525

526

527

528

529

530

531

532

533

534

535

536

537

538

539

540

541

542

543

544

545

546

547

548

549

550

551

552

553

554

555

oleifera and Lannea discolor herbal plants. Scientific African 9: e00481

DOI 10.1016/j.sciaf.2020.e00481.

Najar RA, Fayaz M, Bhat H, Bashir MH, Bashir M, Kumar A, Jain AK. 2018. An efficient micropropagation protocol for direct organogenesis from nodal explants of medicinal climber, Tylophora indica. Bioscience Biotechnology Research Communications 11: 144-153.

Nazir M, Ullah MA, Younas M, Siddiquah A, Shah M, Gigliloli-Guivarc'h N, Hano C, Abbasi BH. 2020. Light-mediated biosynthesis of phenylpropanoid metabolites and antioxidant potential in callus cultures of purple basil (Ocimum basilicum L. var purpurascens). Plant Cell, Tissue and Organ Culture (PCTOC) 142: 107-120.

Oliveira LF, Quoirin M, Koehler HS, Amano E, Higa AR, Ribas LLF. 2013. Propagation from axillary buds and anatomical study of adventitious roots of Pinus taeda L. African Journal of Biotechnology 12: 5413-5422.

Pekal A, Pyrzynska K. 2014. Evaluation of Aluminium Complexation Reaction for Flavonoid Content Assay. Food Analytical Methods 7: 1776-1782.

Petrillo AD, Gonzalez-Paramas AM, Rosa A, Ruggiero V, Boylon F, Kumar A, Pintus F, Santos-Buelga C, Fais A, Era B. 2019. Chemical composition and enzyme inhibition of Phytolacca dioica L. seeds extracts. Journal of Enzyme Inhibition and Medicinal Chemistry 34: 519-527 DOI 10.1080/14756366.2018.1563077.

Sakuta M, Takagi T, Komamine A. 1986. Growth Related Accumulation of Betacyanin in Suspension Cultures of Phytolacca americana L. Journal of Plant Physiology 125: 337-343.

Sakuta M, Hirano H, Komamine A. 1991. Stimulation by 2,4-dichlorophenoxyacetic acid of betacyanin accumulation in suspension cultures of Phytolacca americana. Physiologia Plantarum 83: 154-158.

Sarkar J, Banerjee N. 2020. Influence of different cytokinins on micropropagation of an important medicinal plant, Solanum erianthum D. Don, and assessment of the genetic fidelity of the regenerants. In Vitro Cellular \& Developmental Biology - Plant 56: 480490.

Trunjaruen A, Raso S, Maneerattanaringroj P, Taratima W. 2020. Effects of Cultivation Media on In vitro Callus Induction and Regeneration Capabilities of Pakaumpuel Rice (Oryza sativa L.), Thai Rice Landrace. Walailak Journal of Science and Technology 17: 37-46.

Yang X, Lei Z, Yu Y, Xiao L, Cheng D, Zhang Z. 2019. Phytochemical characteristics of callus suspension culture of Helicteres angustifolia L. and its in vitro antioxidant, antidiabetic and immunomodulatory activities. South African Journal of Botany 121: 178185.

Zang Q, Zhou L, Zhuge F, Yang H, Wang X, Lin X. 2016. Callus induction and regeneration via shoot tips of Dendrocalamus hamiltonii. SpringerPlus 5: Article 1799 DOI 10.1186/s40064-016-3520-7. 
556 Zhang Y, Bozorov TA, Li DX, Zhou P, Wen XJ, Ding Y, Zhang DY. 2020. An efficient in 557 vitro regeneration system from different wild apple (Malus sieversii) explants. Plant $558 \quad$ Methods 16: Article 56.

559 Zou L, Suzhi X, Hujim Y, Yua M, Wang X. 2008. Tissue culture and rapid propagation of 560 Phytolacca americana. Journal of Chinese Medicinal Materials 31: 1299-1301. 


\section{Table $\mathbf{1}$ (on next page)}

Callus induction percentage of different pokeweed explants affected by various types and concentration of auxins 
Table 1 Callus induction percentage of different pokeweed explants affected by various types and concentration of auxins

\begin{tabular}{|c|c|c|c|c|c|}
\hline \multirow[b]{2}{*}{ Explants } & \multicolumn{2}{|c|}{ PGRs } & \multirow[b]{2}{*}{$\begin{array}{l}\text { Callus induction } \\
\qquad \%)\end{array}$} & \multirow[b]{2}{*}{ Fresh weight (mg) } & \multirow[b]{2}{*}{ Dry weight (mg) } \\
\hline & Auxins & $\begin{array}{l}\text { Conc. } \\
(\mathrm{mg} / \mathrm{l})\end{array}$ & & & \\
\hline \multirow{9}{*}{ Cotyledon } & control & 0 & $0.00 \pm 0.0^{e}$ & $0.00 \pm 0.0^{k}$ & $0.00 \pm 0.0^{f}$ \\
\hline & \multirow{4}{*}{$2,4-\mathrm{D}$} & 1 & $100.00 \pm 0.0^{a}$ & $0.44 \pm 0.0^{g}$ & $0.03 \pm 0.0^{c}$ \\
\hline & & 2 & $100.00 \pm 0.0^{a}$ & $0.54 \pm 0.0 e f$ & $0.03 \pm 0.0^{c}$ \\
\hline & & 3 & $100.00 \pm 0.0^{a}$ & $0.49 \pm 0.0^{f g}$ & $0.03 \pm 0.0^{c}$ \\
\hline & & 4 & $100.00 \pm 0.0^{a}$ & $0.53 \pm 0.0^{e f}$ & $0.03 \pm 0.0^{c}$ \\
\hline & \multirow{4}{*}{ IBA } & 1 & $0.00 \pm 0.0^{e}$ & $0.00 \pm 0.0^{k}$ & $0.00 \pm 0.0^{f}$ \\
\hline & & 2 & $0.00 \pm 0.0^{e}$ & $0.00 \pm 0.0^{k}$ & $0.00 \pm 0.0^{f}$ \\
\hline & & 3 & $0.00 \pm 0.0^{e}$ & $0.00 \pm 0.0^{k}$ & $0.00 \pm 0.0^{f}$ \\
\hline & & 4 & $0.00 \pm 0.0^{e}$ & $0.00 \pm 0.0^{k}$ & $0.00 \pm 0.0^{f}$ \\
\hline \multirow{9}{*}{ Leaf } & control & 0 & $0.00 \pm 0.0^{e}$ & $0.00 \pm 0.0^{k}$ & $0.00 \pm 0.0^{f}$ \\
\hline & \multirow{4}{*}{$2,4-\mathrm{D}$} & 1 & $100.00 \pm 0.0^{a}$ & $0.70 \pm 0.0^{b}$ & $0.04 \pm 0.0^{b}$ \\
\hline & & 2 & $100.00 \pm 0.0^{a}$ & $0.80 \pm 0.0^{a}$ & $0.05 \pm 0.0^{a}$ \\
\hline & & 3 & $100.00 \pm 0.0^{a}$ & $0.69 \pm 0.1^{b}$ & $0.04 \pm 0.0^{b}$ \\
\hline & & 4 & $100.00 \pm 0.0^{a}$ & $0.75 \pm 0.0^{a b}$ & $0.04 \pm 0.0^{b}$ \\
\hline & \multirow{4}{*}{ IBA } & 1 & $0.00 \pm 0.0^{e}$ & $0.00 \pm 0.0^{k}$ & $0.00 \pm 0.0^{f}$ \\
\hline & & 2 & $0.00 \pm 0.0^{e}$ & $0.00 \pm 0.0^{k}$ & $0.00 \pm 0.0^{f}$ \\
\hline & & 3 & $0.00 \pm 0.0^{e}$ & $0.00 \pm 0.0^{k}$ & $0.00 \pm 0.0^{f}$ \\
\hline & & 4 & $0.00 \pm 0.0^{e}$ & $0.00 \pm 0.0^{k}$ & $0.00 \pm 0.0^{f}$ \\
\hline \multirow{9}{*}{ Internode } & control & 0 & $0.00 \pm 0.0^{e}$ & $0.00 \pm 0.0^{k}$ & $0.00 \pm 0.0^{f}$ \\
\hline & \multirow{4}{*}{$2,4-\mathrm{D}$} & 1 & $100.00 \pm 0.0^{a}$ & $0.22 \pm 0.0^{j}$ & $0.01 \pm 0.0^{e}$ \\
\hline & & 2 & $100.00 \pm 0.0^{a}$ & $0.21 \pm 0.0^{j}$ & $0.01 \pm 0.0^{e}$ \\
\hline & & 3 & $100.00 \pm 0.0^{a}$ & $0.24 \pm 0.0^{j}$ & $0.01 \pm 0.0^{e}$ \\
\hline & & 4 & $100.00 \pm 0.0^{a}$ & $0.22 \pm 0.0^{j}$ & $0.01 \pm 0.0^{e}$ \\
\hline & \multirow{4}{*}{ IBA } & 1 & $56.25 \pm 14.7^{c}$ & $0.30 \pm 0.0^{i}$ & $0.02 \pm 0.0^{d}$ \\
\hline & & 2 & $62.50 \pm 12.5^{c}$ & $0.35 \pm 0.0^{h i}$ & $0.03 \pm 0.0^{c}$ \\
\hline & & 3 & $56.25 \pm 11.3^{c}$ & $0.35 \pm 0.1^{h i}$ & $0.03 \pm 0.0^{c}$ \\
\hline & & 4 & $37.50 \pm 12.5^{d}$ & $0.38 \pm 0.0^{h}$ & $0.03 \pm 0.0^{c}$ \\
\hline \multirow{9}{*}{ Node } & control & 0 & $0.00 \pm 0.0^{e}$ & $0.00 \pm 0.0^{k}$ & $0.00 \pm 0.0^{i}$ \\
\hline & \multirow{4}{*}{$2,4-\mathrm{D}$} & 1 & $100.00 \pm 0.0^{a}$ & $0.61 \pm 0.0^{c d}$ & $0.04 \pm 0.0^{b}$ \\
\hline & & 2 & $100.00 \pm 0.0^{a}$ & $0.56 \pm 0.0^{d-f}$ & $0.03 \pm 0.0^{c}$ \\
\hline & & 3 & $100.00 \pm 0.0^{a}$ & $0.56 \pm 0.0^{c-e}$ & $0.03 \pm 0.0^{c}$ \\
\hline & & 4 & $100.00 \pm 0.0^{a}$ & $0.58 \pm 0.0^{c-e}$ & $0.04 \pm 0.0^{b}$ \\
\hline & \multirow{4}{*}{ IBA } & 1 & $62.50 \pm 8.1^{c}$ & $0.62 \pm 0.0^{c}$ & $0.04 \pm 0.0^{b}$ \\
\hline & & 2 & $81.25 \pm 9.1^{b}$ & $0.61 \pm 0.0^{c d}$ & $0.04 \pm 0.0^{b}$ \\
\hline & & 3 & $62.50 \pm 8.1^{c}$ & $0.81 \pm 0.0^{a}$ & $0.05 \pm 0.0^{a}$ \\
\hline & & 4 & $56.25 \pm 6.2^{c}$ & $0.59 \pm 0.0^{c-e}$ & $0.04 \pm 0.0^{b}$ \\
\hline
\end{tabular}

2 Means \pm SE followed by different letters are significantly different by ANOVA and least

3 significant difference tests $(p<0.05)$. Different letters $(a, b, c \ldots)$ represent significant

4 differences in columns $(p<0.05)$. 
Table 2 (on next page)

Direct shoot organogenesis from nodal explants of pokeweed influenced by various types and concentrations of cytokinins 
Table 2 Direct shoot organogenesis from nodal explants of pokeweed influenced by various types and concentrations of cytokinins

\begin{tabular}{cccccc}
\hline Cytokinins & Root & Shoot & Number of & Shoot length & Number of \\
Conc. & formation $(\%)$ & formation $(\%)$ & shoots & $(\mathrm{cm})$ & leaves \\
$(\mathrm{mg} / \mathrm{l})$ & & & & &
\end{tabular}

Control
0
$31.25 \pm 9.1^{a}$
$37.50 \pm 8.1^{b}$
$1.00 \pm 0.0^{c}$
$4.41 \pm 0.4^{a b}$
$6.06 \pm 0.4^{d}$

BAP

$\begin{array}{llllll}1 & 0.00 \pm 0.0^{b} & 100.00 \pm 0.0^{a} & 2.18 \pm 0.1^{a b} & 4.18 \pm 0.1^{b} & 9.50 \pm 0.3^{a b} \\ 2 & 0.00 \pm 0.0^{b} & 100.00 \pm 0.0^{a} & 2.06 \pm 0.1^{a b} & 3.82 \pm 0.1^{b c} & 8.81 \pm 0.5^{b c} \\ 4 & 0.00 \pm 0.0^{b} & 100.00 \pm 0.0^{a} & 1.25 \pm 0.1^{c} & 2.49 \pm 0.1^{e} & 5.56 \pm 0.6^{d}\end{array}$

Kinetin

1

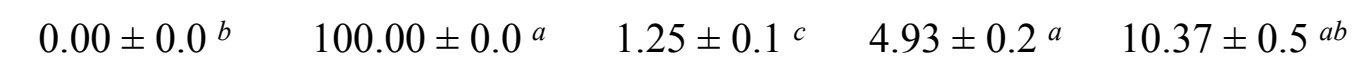

$0.00 \pm 0.0^{b}$

$100.00 \pm 0.0^{a}$

$1.81 \pm 0.1^{b}$

$5.04 \pm 0.2^{a}$

$10.93 \pm 0.7^{a}$

4

$0.00 \pm 0.0^{b} \quad 100.00 \pm 0.0^{a}$

$2.12 \pm 0.2^{a b}$

$3.82 \pm 0.1^{b c}$

$9.50 \pm 0.8^{a b}$

TDZ

$\begin{array}{llllll}1 & 0.00 \pm 0.0^{b} & 100.00 \pm 0.0^{a} & 2.43 \pm 0.2^{a} & 3.12 \pm 0.2^{d e} & 7.18 \pm 0.5^{c d} \\ 2 & 0.00 \pm 0.0^{b} & 100.00 \pm 0.0^{a} & 2.18 \pm 0.1^{a b} & 2.93 \pm 0.1^{d e} & 7.06 \pm 0.6^{d} \\ 4 & 0.00 \pm 0.0^{b} & 100.00 \pm 0.0^{a} & 1.81 \pm 0.1^{b} & 3.44 \pm 0.2^{c d} & 6.93 \pm 0.5^{d}\end{array}$

1 Means \pm SE followed by different letters are significantly different by ANOVA and least

2 significant difference tests $(p<0.05)$. Different letters $(a, b, c \ldots)$ represent significant

3 differences in columns $(p<0.05)$. 


\section{Table 3(on next page)}

Combined effects of cytokinins and NAA on direct shoot organogenesis from pokeweed nodal explants 
Table 3 Combined effects of cytokinins and NAA on direct shoot organogenesis from pokeweed nodal explants

\begin{tabular}{|c|c|c|c|c|c|c|}
\hline \multicolumn{2}{|c|}{ PGRs } & \multirow[b]{2}{*}{$\begin{array}{c}\text { Roots } \\
\text { formation (\%) }\end{array}$} & \multirow[b]{2}{*}{$\begin{array}{c}\text { Shoots } \\
\text { formation }(\%)\end{array}$} & \multirow[b]{2}{*}{ Shoots number } & \multirow[b]{2}{*}{ Shoot length } & \multirow[b]{2}{*}{$\begin{array}{l}\text { Leaves } \\
\text { number }\end{array}$} \\
\hline Cytokinins & $\begin{array}{l}\text { NAA } \\
\text { conc. } \\
(\mathrm{mg} / \mathrm{l})\end{array}$ & & & & & \\
\hline \multirow[t]{2}{*}{ Control } & & $31.25 \pm 9.15^{a}$ & $37.50 \pm 8.18^{b}$ & $1.00 \pm 0.00^{e}$ & $4.41 \pm 0.49^{a b}$ & $6.06 \pm 0.49^{c d}$ \\
\hline & 0 & $0.00 \pm 0.00^{b}$ & $100.00 \pm 0.00^{a}$ & $2.18 \pm 0.16^{a-c}$ & $4.18 \pm 0.13^{b}$ & $9.50 \pm 0.37^{b}$ \\
\hline $1 \mathrm{mg} / \mathrm{l}$ & 0.1 & $0.00 \pm 0.00^{b}$ & $100.00 \pm 0.00^{a}$ & $2.06 \pm 0.19^{a-d}$ & $3.86 \pm 0.11^{b}$ & $7.25 \pm 0.50^{c}$ \\
\hline \multirow[t]{3}{*}{ BAP } & 0.2 & $0.00 \pm 0.00^{b}$ & $100.00 \pm 0.00^{a}$ & $1.68 \pm 0.17^{c d}$ & $3.80 \pm 0.11^{b}$ & $6.43 \pm 0.34^{c d}$ \\
\hline & 0.3 & $0.00 \pm 0.00^{b}$ & $100.00 \pm 0.00^{a}$ & $1.43 \pm 0.15^{d e}$ & $3.18 \pm 0.18^{c d}$ & $7.12 \pm 0.40^{c}$ \\
\hline & 0 & $0.00 \pm 0.00^{b}$ & $100.00 \pm 0.00^{a}$ & $1.81 \pm 0.16^{b-d}$ & $5.04 \pm 0.22^{a}$ & $10.93 \pm 0.70^{a}$ \\
\hline $2 \mathrm{mg} / 1$ & 0.1 & $0.00 \pm 0.00^{b}$ & $100.00 \pm 0.00^{a}$ & $2.50 \pm 0.32^{a}$ & $3.16 \pm 0.19^{c d}$ & $5.25 \pm 0.44^{d}$ \\
\hline \multirow[t]{3}{*}{ KIN } & 0.2 & $0.00 \pm 0.00^{b}$ & $100.00 \pm 0.00^{a}$ & $2.50 \pm 0.30^{a}$ & $2.98 \pm 0.25^{d}$ & $5.25 \pm 0.49^{d}$ \\
\hline & 0.3 & $0.00 \pm 0.00^{b}$ & $100.00 \pm 0.00^{a}$ & $1.93 \pm 0.21^{a-d}$ & $2.79 \pm 0.23^{d}$ & $6.81 \pm 0.66^{c}$ \\
\hline & 0 & $0.00 \pm 0.00^{b}$ & $100.00 \pm 0.00^{a}$ & $2.43 \pm 0.25 a b$ & $3.12 \pm 0.21^{d}$ & $7.18 \pm 0.57^{c}$ \\
\hline $1 \mathrm{mg} / 1$ & 0.1 & $0.00 \pm 0.00^{b}$ & $100.00 \pm 0.00^{a}$ & $2.37 \pm 0.28^{a b}$ & $3.21 \pm 0.18^{c d}$ & $7.31 \pm 0.29^{c}$ \\
\hline \multirow[t]{2}{*}{ TDZ } & 0.2 & $0.00 \pm 0.00^{b}$ & $100.00 \pm 0.00^{a}$ & $1.73 \pm 0.26^{c d}$ & $2.60 \pm 0.15^{d}$ & $6.00 \pm 0.34^{c d}$ \\
\hline & 0.3 & $0.00 \pm 0.00^{b}$ & $100.00 \pm 0.00^{a}$ & $1.68 \pm 0.23^{c d}$ & $2.96 \pm 0.18^{d}$ & $6.62 \pm 0.42^{c}$ \\
\hline
\end{tabular}

2 Means \pm SE followed by different letters are significantly different according to ANOVA and

3 Least Significant Different Test $(p<0.05)$. Different letters $(\mathrm{a}, \mathrm{b}, \mathrm{c} \ldots)$ represent significant

4 differences in columns $(p<0.05)$.

5

6

7 


\section{Table 4 (on next page)}

TPC, TFC and IC $\mathrm{C}_{50}$ by DPPH assay of different types of pokeweed explants 
Table 4 TPC, TFC and $\mathrm{IC}_{50}$ by DPPH assay of different types of pokeweed explants

\begin{tabular}{cccc}
\hline Explant types & TPC & TFC & IC $_{50}$ by DPPH assay \\
& $(\mathrm{mg} \mathrm{GAE} / \mathrm{g}$ extract $)$ & $(\mathrm{mg} \mathrm{QE} / \mathrm{g}$ extract $)$ & $(\mu \mathrm{g} / \mathrm{ml})$ \\
\hline Callus & $26.03 \pm 0.6^{b}$ & $11.73 \pm 0.5^{d}$ & $341.99 \pm 15.3^{b}$ \\
Leaf & $28.56 \pm 0.4^{b}$ & $57.31 \pm 0.7^{a}$ & $228.70 \pm 4.0^{c}$ \\
Root & $14.03 \pm 0.3^{b}$ & $33.46 \pm 1.2^{c}$ & $1125.51 \pm 21.5^{a}$ \\
Seed & $155.83 \pm 8.6^{a}$ & $49.81 \pm 1.3^{b}$ & $12.66 \pm 0.6^{d}$ \\
Ascorbic acid & - & - & $3.91 \pm 0.0^{d}$ \\
\hline
\end{tabular}

1 Means \pm SE followed by different letters are significantly different by ANOVA and least

2 significant different tests $(p<0.05)$. Different letters $(a, b, c \ldots)$ represent significant difference 3 in columns $(p<0.05)$.

4 


\section{Figure 1}

In vitro calli and plantlets grown on MS media supplemented with different PGRs.

(A) Leaf explants cultured on MS medium with 4 mg/l IBA; (B) Nodal explants cultured on MS medium with $3 \mathrm{mg} / \mathrm{IBA}$; (C) Nodal explants cultured on MS medium at four weeks; (D) Callus with purple pigment inside the cells (arrow) and elongated clear cells (arrowhead); (E) Leaf explants cultured on MS medium with 2 mg/l 2,4-D; (F) Nodal explants cultured on MS medium at six weeks; (G) Nodal explants cultured on MS medium with $1 \mathrm{mg} / \mathrm{l} \mathrm{BAP}$; (H) Nodal explants cultured on MS medium with $1 \mathrm{mg} / \mathrm{IDZ}$; (I) Nodal explants cultured on MS medium with $2 \mathrm{mg} / \mathrm{l} \mathrm{kinetin;} \mathrm{scale}=1 \mathrm{~cm}(\mathrm{~A}-\mathrm{C}, \mathrm{E}-\mathrm{I})$; scale $=500 \mu \mathrm{m}$ (D). 

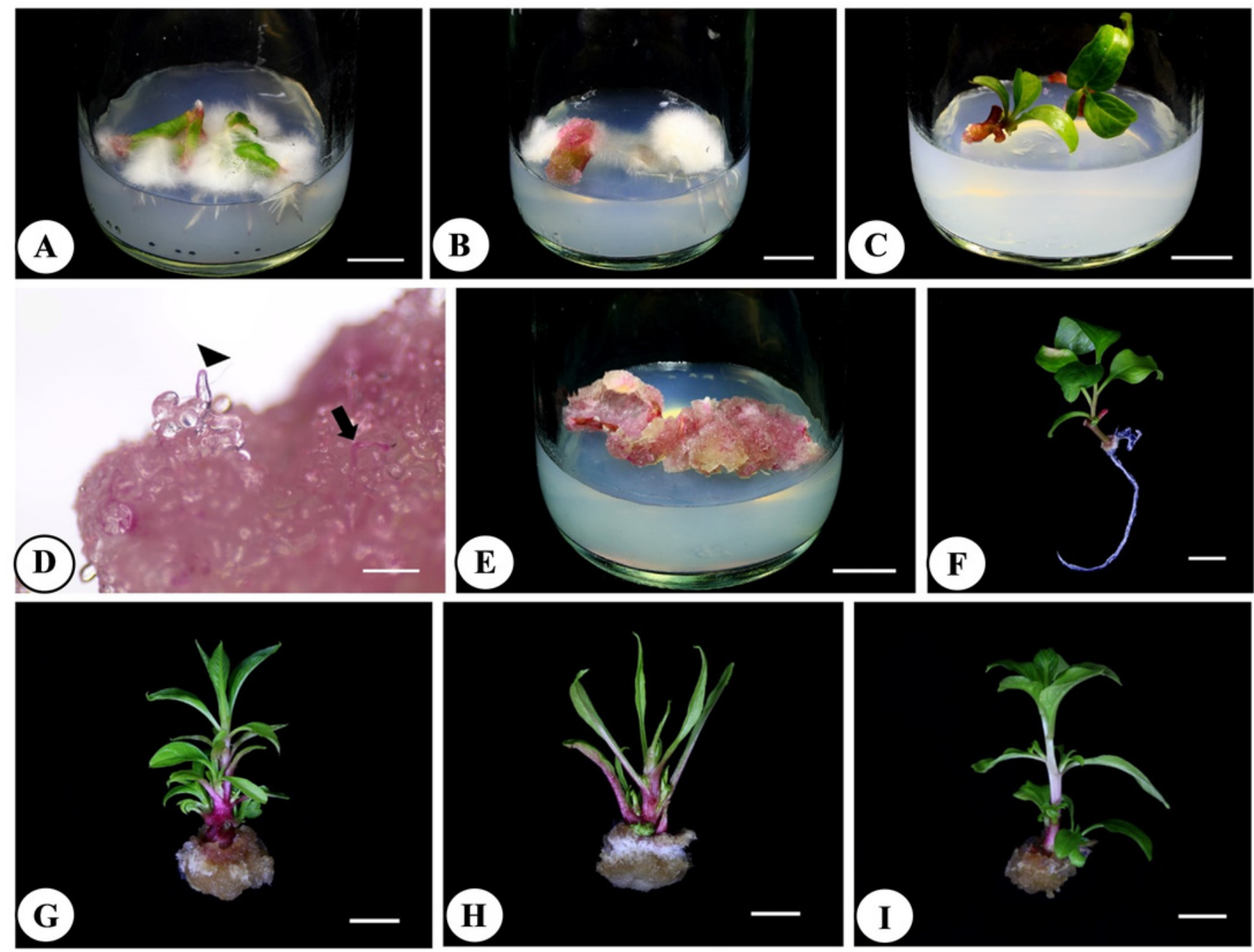